\title{
GROWTH AND PRODUCTIVITY OF "ANNA" APPLE TREES (Malus domestica Borkh.) FOLLOWING DORMANT PRUNING TREATMENTS
}

(Received: 25.11.2009)

\author{
By \\ A. T. Abo-El-Ez \\ Horticulture Department, Faculty of Agriculture, Sohag University, Sohag, Egypt.
}

\begin{abstract}
This investigation was carried out during three successive seasons (2007, 2008 and 2009) to study the effect of different dormant pruning treatments on 5-years old "Anna" apple trees budded on "Malus" apple rootstock grown in El-Kawamel region, Sohag, where soil is sandy, under drip irrigation system to determine the optimal degree of dormant pruning severity to increase yield and improve fruit quality. Severe dormant pruning treatment (thinning out $60 \%$ of one -year-old shoots/tree) significantly decreased number of shoots/branch. In contrast, there were clear trends of increase in number of leaves/shoot, specific leaf weight, leaf total chlorophyll content, total soluble sugars, starch percentage and total carbohydrates as dormant pruning severity increased. All dormant pruning treatments affected total number of flowers/branch, and the effect was decreased as severity of pruning increased. On the other hand, the increase in the number of flowers/ spur was positively associated with pruning severity. Light (thinning out $20 \%$ of shoots/tree) and moderate (thinning out $40 \%$ of shoots/tree) dormant pruning treatments significantly increased the percentage of fruit set and improved yield (fruit weight/tree), and the improvement was inversely proportional to the severity of pruning. Dormant pruning treatments increased average fruit weight, but decreased fruit firmness in respect to its severity in the three seasons. All dormant pruning treatments affected total acidity and total starch \% and the effect was decreased as severity of pruning was increased, while the increase in total soluble solids and total sugars were positively associated with pruning severity. Severe and moderate (thinning out $60 \%$ and $40 \%$ of shoots/tree) dormant pruning treatments significantly increased red color $\%$ and peel anthocyanin content.

From the results, it could be recommended that apple (Anna /Malus) growers should prune their trees moderately (by thinning out $40 \%$ of shoots/tree) to increase flowering and fruit set, which in turn increase yield and fruit quality.
\end{abstract}

Keyword: apple, apple cv "Anna", dormant pruning, flowering, fruit set, yield and fruit quality, leaf chlorophyll content, Malus domestica, organic constituent, thinning out, vegetative growth.

\section{INTRODUCTION}

Apples are the fourth most important world fruit crop after oranges, bananas and grapes. In Egypt, production of apple has increased considerably after introducing low chilling requirement, high productivity and regular bearing cultivars from the U.S.A. in 1980 , such as Anna, Dorsett Golden, Ein Shemer and others. Anna is the most important of all the introduced cultivars (Stino et al., 1985; Zayan and Morsy, 1989 and Kilany and Kilany, 1991).

Determining the most appropriate pruning type for a given cultivar is a risk benefit assessment that requires an intimate knowledge of the specific types of pruning cuts and the usual responses to them. Pruning must be a compromise between optimal benefits and adverse effects, such as reduced fruiting and increased shoot growth. Any how, amount and type of pruning that are most appropriate will vary with many factors such as tree density (Parry, 1981), management system (Mika, 1986 and Elfving and Cline, 1990). rootstocks (Harber et al., 1992), scion cultivar (Marini and Barden, 1987) and fruit bearing habit (Marini and Sowers, 1991).

Physiologically, dormant pruning influences photosynthesis by improving the interception of light and its distribution within the tree canopy (Cain, 1973; Porpiglia and Barden, 1980 and Mika, 1986). Moreover, on one hand, the removal of buds in dormant pruning reduces leaf area and photosynthetic potential early in the growing season. On the other hand, the pruning induced increase in shoot growth is a compensating factor, and the total leaf surface of the pruned tree is comparable to that of unpruned ones by mid summer. Previous studies have analyzed tree responses to dormant pruning (thinning out) and 
impacts on growth, flowering and leaf organic constituents, fruit set, yield and fruit quality in several deciduous fruit species.

Dormant pruning had little effect on shoot growth of peach (Marini, 1985), while severe dormant pruning treatments decreased all determined shoot growth parameters. On the other hand, there are clear trends of increase in number of leaves per shoot and specific leaf weight as dormant pruning severity of apple increased (Cain, 1973; Barden, 1974; Forshey and Marmo, 1985; Ferree and Forshey, 1988; Barden et al., 1989; Zayan et al., 2002 and Gabr et al., 2006).

The percent of flower buds was greatly decreased by dormant pruning. The reduction in flower formation could provide the condition for breaking alternate bearing of apple (Bertschinger et al., 1997). On one hand, total number of flowers per branch was decreased as severity of pruning was increased. On the other hand, the increase in number of flowers per spur was positively associated with pruning severity of apple and apricot (Lakso et al., 1978; Mika, 1986; Barden et al., 1989; Abd El-Wahab et al., 2002; Zayan et al., 2002 and Ebied, 2005). There are clear trend of increase in total chlorophyll content of plum (Dinkova, 1997), apricot (Gabr et al., 2006) and apple (Porpiglia and Barden, 1980; Mika, 1986 and Zayan et al., 2002), as well as total soluble sugars, starch percentage and total carbohydrate of apple as dormant pruning severity increased (Barden, 1974; Mika, 1986 and Zayan et al., 2002).

Light and moderate dormant pruning increased fruit set percentage of apple (Lord et al., 1979; Mika, 1986 and Zayan et al., 2002). Pruning reduced yield of apple (Sus et al., 1997). Light and moderate dormant pruning improved yield of apple as weight or fruit number/tree, and the improvement was inversely proportional to the severity of pruning (Mika, 1986; Babcock et al., 1992; Kuden et al., 1997 and Zayan et al., 2002).

Dormant pruning increased average fruit weight in proportion to its severity (Ferree and Forshey, 1988; Fathi and Mokhtar, 1998; Zayan et al., 2002 and Gabr et al., 2006). Dormant pruning had no effect on soluble solids and total acidity percent of apple fruits (Fathi and Mokhtar, 1998; Ferree and Forshey, 1988, Gabr and Ibrahim, 2005 and Gabr et al., 2006). The most severe treatment only increased the percentage of total soluble solids compared with the control (Zayan et al., 2002). Dormant pruning increased colored fruit percentage (Proctor and Creasy, 1971; Lakso et al., 1978; Mika, 1986 and Zayan et al., 2002). However, low vigor trees developed more colored fruits than high vigor trees (Raese and Williams, 1974).

The objective of this work was to evaluate the different effects of dormant pruning (thinning out) on growth behavior, flowering, leaf organic components (total chlorophyll content, total soluble sugars, starch percentage and total carbohydrates), fruit set, yield and fruit quality of "Anna" apple trees budded on Malus rootstock, and grown in sandy soil at El-Kawamel region where "Anna" apple trees produce small less colored fruits.

\section{MATERIALS AND METHODS}

The presented study was undertaken during the three successive seasons of 2007, 2008 and 2009 on 5-year-old "Anna" apple (Malus domestica Borkh.) trees budded on the vigorous rootstock (Malus sylvestriscl Mill). The selected trees were planted in the orchard of Sohag Univ. at ElKawamel region, Sohag Governorate, in sandy soil and spaced at $5 \times 5$ meter apart with (1:8) Dorsett Golden pollinator to "Anna" apple cultivar. The trees were trained as open-vase form. The selected trees were chosen as uniform in vigor size and normal growth.

The "Anna" apple trees selected for carrying out the experiment received basal application of recommended NPK nutrition which included the addition of $2 \mathrm{~kg}$ ammonium nitrate $(33.5 \% \mathrm{~N}), 1$ $\mathrm{kg}$ monocalcium superphosphate $\left(\begin{array}{lll}15.5 \% & \mathrm{P}_{2} \mathrm{O}_{2}\end{array}\right)$ and $1 \mathrm{~kg}$ potassium sulphate $\left(48 \% \mathrm{~K}_{2} \mathrm{O}\right)$ per tree. Farmyard manure $\left(0.25 \% \mathrm{~N}, 1.2 \% \mathrm{~K}_{2} \mathrm{O}\right.$ and $0.8 \%$ $\mathrm{P}_{2} \mathrm{O}_{2}$ ) was added to all the trees at $10 \mathrm{~kg} /$ tree as recommended by the Ministry of Agriculture, and the trees were irrigated by a drip system.

\subsection{Experimental Design}

The experiment was conducted on twenty four trees of apple cv. Anna. In the three seasons, four treatments (including the control) were carried out, each replicated three times with two trees per replicate, using a randomized complete block design.

\subsection{Experimental work}

Three pruning treatments were used for apple "Anna" trees. Eighteen trees were pruned in January with three degrees of severity, by removing 20, 40, 60\% of one-year-old shoots. Control trees included six trees (two trees/ replicate) without pruning.

Three main branches from different directions per tree were labeled to determine the following measurements.

\subsection{Vegetative growth measurements}

At the end of each growing seasons, all current shoots developed on the main branches were 
counted. Number of leaves per shoot were counted and the average was recorded.

\subsection{Leaf organic components}

Leaf samples were collected at the end of June of each season from the middle portion of the current outer non-bearing shoots. Each sample consisted of twenty five leaves, and was used to calculate specific leaf weight $\left(\mathrm{mg} / \mathrm{cm}^{2}\right)$ as described by Ferree and Forshey (1988). Starch, total soluble sugars and total carbohydrates were determined according to Somogy (1952) and Nelson (1974).

\subsection{Leaf total chlorophyll}

Fresh leaf samples was taken in June of each season from each replicate for extraction and determination of chlorophyll spectrophotometrically, as described by Rami and Porath (1980). The concentration of total chlorophyll was calculated by Rami's formulas as $\mu \mathrm{g} / \mathrm{ml}$ (Rami, 1982). The results were presented as $\left(\mathrm{mg} / \mathrm{cm}^{2}\right)$ of leaf blade.

\subsection{Flowering measurements}

The number of flowers was determined on all labeled branches for each experimental tree at full bloom (mid Mar.). Also, average flower number per spur was determined.

\subsection{Fruit set percentage}

The percentage of fruit set was determined on the basis of the number of fruitlets set on each labeled branch on all experimental trees, thirty days after full bloom, according to the following equation:

$$
\text { Fruit set } \%=\frac{\text { Number of fruitlets }}{\text { Number of flowers }} \times 100
$$

\subsection{Yield per tree and alternate bearing index}

Fruits were harvested at maturity stage (mid June) from all trees of the three replicates, and yield was recorded as number and weight $(\mathrm{kg})$ in the three seasons. The index of alternate bearing for individual trees was estimated according to the following equation suggested by Wilcox (1944):

Alternate bearing index $=100 \mathrm{x}$ (difference between two successive yields/sum of two successive yields). If the result is more than $25 \%$ this means that the tree has an alternate bearing habit, while the tree has regular bearing if the result is less than $25 \%$.

\subsection{Fruit quality}

A sample of five fruits from each tree was harvested on mid June in the three seasons to determine the following measurements.

\subsubsection{Physical properties}

Fruit weight $(\mathrm{g})$ and fruit firmness $\left(\mathrm{lb} / \mathrm{inch}^{2}\right)$ were determined by the method described by Magness and Taylor (1925) using a 5/16 pressure plunger. Total anthocyanin content in skin of
"Anna" apple fruits was determined using the method described by Hisa et al., (1965).

\subsubsection{Chemical properties}

Total soluble solids (TSS) percentage was determined by using a hand refractometer, while total acidity percentage was estimated as malic acid/100 g. fresh weight according to A.O.A.C. (1975). The total sugars of each sample $(0.5 \mathrm{~g}$ ground dried material) were extracted by distilled water (Dubois et al., 1956) and the starch content was determined in the residue remaining after sugar extraction (A.O.A.C., 1975). The different carbohydrate fractions were expressed as percents on fresh weight basis.

\subsection{Statistical analysis}

The obtained data were statistically analyzed using the MSTAT-C statistical analysis package (Freed et al., 1989), then LSD test was used to recognize the significance of differences between the treatment means, according to the procedure of Snedecor and Cochran (1972).

\section{RESULTS AND DISCUSSION \\ 3.1. Growth behavior}

All vegetative growth characters measured were significantly affected by dormant pruning treatments applied in the three seasons (Tables $1 \& 2)$.

Data in Table (1) indicate that thinning out $40 \%$ of shoots/branch gave the highest significant number of shoots/branch, followed by thinning out $20 \%$ of shoots/branch, then the control (in the three seasons). On the other hand thinning out $60 \%$ of shoots/branch gave significantly lower values.

The obtained results are in line with those obtained by Forshey and Marmo (1985), Ferree and Forshey (1988), Barden et al.(1989) and Zayan et al.(2002), who reported that apple shoot growth is positively correlated with pruning severity.

In contrast, there are clear trends of increase in number of leaves/shoot and specific leaf weight due to severe dormant pruning treatments Tables (1\&2). This increment was positively associated with severity of pruning. Statistical analysis shows significant differences among treatments and between treatment and control in the three seasons. This result agrees with that obtained by Gabr et al. (2006)

Barden et al.(1989) reported that thinning out at time of dormant pruning reduced number of laterals and increased length of terminals, and the effect was in proportion to pruning severity. This may give a good chance to more leaves to develop leading to the increase in number of leaves per shoot. Since apple leaves are opaque to 
photosynthetic radiation (Cain, 1973), Mika (1986) reported that the thinning out pruning technique increased light penetration into the tree, and Barden (1974) reveled that specific leaf weight was increased in sunny compared with shaded leaves.

Data showed that "Anna" apple leaf content of total chlorophyll (Table 2) was positively affected by pruning and severity. In this respect, control trees recorded the lowest values in all seasons. In the same time, the highest total chlorophyll in apple leaves was obtained from trees pruned by thinning out $60 \%$ of shoots/tree, followed by those pruned by thinning out $40 \%$ of shoots/tree, then thinning out $20 \%$ of shoots/tree.

This result agrees with that obtained by Porpiglia and Barden (1980) and Mika (1986), who found that removing the shoot by dormant pruning led to an accumulation of assimilates in shoots and leaves, as well as increased light pentration through the tree canopy which in turn increased photosynthetic activity of leaves. This accumulation of assimilates and increased light penetration may be a reason to the increase of chlorophyll content in the leaves.

\subsection{Leaf organic constituents}

Concerning leaf total soluble sugars, starch and total carbohydrates percentage (Table 3), it was clear that the effect of treatments on these components was positively associated with pruning severity. In the three seasons, thinning out $20 \%$ of shoots/tree reduced all parameters and recorded the lowest values, while thinning out $60 \%$ of shoots/tree recorded the highest values of these components, followed by thinning out $40 \%$ of shoots/tree, then the control treatment.

The obtained results are in accordance with those obtained by Barden (1974) and Mika (1986) who reported that dormant pruning improved light interception and distribution within the tree canopy, which led to increasing net photosynthetic potencial of pruned trees. Mika (1986) attributed the stimulation of photosynthetic activity of leaves by dormant pruning to an enlargement of leaf mesophyll cell size, an increase in chlorophyll content and a lengthening of the daily period of stomata opening caused by an increased leaf water content. The stimulated photosynthetic activity caused by increasing leaf efficiency resulted in an increase in total carbohydrate.

\subsection{Flowering}

Data in Table (4) reveal that, in most cases, dormant pruning treatments enhanced flowering, in most cases of "Anna" apple trees. It was clear that dormant pruning treatments increased the number of flowers/spur and the effect was positively associated with pruning severity. In general thinning out $20 \%$ or $40 \%$ of the shoots increased the total number of flowers per branch, with light pruning (removal of $20 \%$ of the shoots) being mare effective in this respect. On the other hand, severe pruning (removal of 60\% of the shoots) caused a significant reduction in the number of flowers/ brench, compared to that of control trees. Lakso et al. (1978) and Abd ElWahab et al. (2002) found that dormant pruning enhanced flowering of apple trees, which give support to the obtained results. The relationships between dormant pruning types, penetration of photosynthetically activite radiation, production of new spurs and flower intiation and differentiation were discussed by Propiglia and Barden (1980) and Mika (1986). They concluded that dormant pruning improved penetration and distribution of photosynthetically active radiation through the interior parts of the tree canopy above the minimum required for flower initiation which, in turn, induced production of new spurs on the pruned trees and increased the percentage of flowering spurs.

\subsection{Fruit set}

As shown in Table (5) it is clear that thinning out $20 \%$ and $40 \%$ of shoots/tree significantly increased the percentage of fruit set in the three seasons, while thinning out $60 \%$ of shoots/tree gradually reduced the fruit set percentage as seasons advanced.

The obtained results are in accordance with those of Lord et al. (1979) and Zayan et al. (2002), who found that dormant pruning increased fruit set. In addition Mika (1986) reported that fruit retention or abscission is influenced by level of endogenous hormones (auxins, gibberellin, cytokinins and ethylene) both directly and indirectly shifting translocation of assimilates to the competing areas of the growing shoots and fruit. Since pruning modifies hormonal levels, it is possible that pruning can increase fruit set as a result of modification of growth hormones.

\subsection{Yield per tree and alternate bearing index}

Data in Table (5) show that yield of "Anna" apple trees was affected by pruning. It was clear that thinning out $20 \%$ of shoots/tree increased the fruit yield ( $\mathrm{kg} /$ tree), followed by thinning out $40 \%$ of shoots/tree, while thinning out $60 \%$ of shoots/tree produced the lowest yield/tree in comparison with the control. Data in Table (4) reveal that dormant pruning treatments enhanced yield of "Anna" apple trees by increasing number of flowers on spurs and total number of flowers per branch, and increasing fruit set, which directly affected yield/tree.

These results are in line with those of Mika (1986), Babcock et al. (1992), Kuden at el. (1997) 
Table (1): Effect of dormant pruning treatments on number of shoots/branch and leaf number/shoot of "Anna" apple trees during 2007, 2008 and 2009 seasons.

\begin{tabular}{|l|c|c|c|c|c|c|}
\hline \multirow{2}{*}{ Pruning treatments } & \multicolumn{3}{|c|}{ Number of shoots/branch } & \multicolumn{3}{c|}{ Leaf number/shoot } \\
\cline { 2 - 7 } & $\mathbf{2 0 0 7}$ & $\mathbf{2 0 0 8}$ & $\mathbf{2 0 0 9}$ & $\mathbf{2 0 0 7}$ & $\mathbf{2 0 0 8}$ & $\mathbf{2 0 0 9}$ \\
\hline Control & 19.25 & 19.31 & 18.26 & 29.93 & 30.60 & 28.53 \\
\hline Thinning out 20\% & 20.32 & 20.39 & 19.27 & 27.65 & 28.98 & 25.66 \\
\hline Thinning out 40\% & 22.50 & 22.59 & 21.34 & 33.74 & 34.87 & 31.80 \\
\hline Thinning out 60\% & 15.25 & 15.32 & 14.46 & 39.34 & 40.45 & 37.20 \\
\hline LSD at 5\% level & 0.16 & 0.23 & 0.32 & 0.21 & 0.43 & 0.25 \\
\hline
\end{tabular}

Table (2): Effect of dormant pruning treatments on specific leaf weight and total chlorophyll $\left(\mathrm{mg}^{\mathrm{cm}} \mathrm{cm}^{2}\right) \mathrm{of}^{2}$ "Anna" apple trees during 2007, 2008 and 2009 seasons.

\begin{tabular}{|l|c|c|c|c|c|c|}
\hline \multirow{2}{*}{\begin{tabular}{|} 
Pruning treatments \\
"Anna" apple trees during 2007, 2008 and 2009 seasons.
\end{tabular}} & \multicolumn{4}{c|}{$\begin{array}{c}\text { Total chlorophyll } \\
\left(\mathrm{mg} / \mathrm{cm}^{2}\right)\end{array}$} \\
\cline { 2 - 7 } & 2007 & 2008 & 2009 & 2007 & 2008 & 2009 \\
\hline Control & 11.13 & 11.17 & 11.07 & 6.647 & 6.767 & 6.497 \\
\hline Thinning out 20\% & 12.35 & 12.28 & 12.43 & 7.130 & 7.280 & 6.927 \\
\hline Thinning out 40\% & 12.50 & 12.51 & 12.41 & 7.257 & 7.297 & 7.217 \\
\hline Thinning out 60\% & 12.49 & 12.56 & 12.48 & 7.640 & 7.550 & 7.750 \\
\hline LSD at 5\% level & 0.01 & 0.02 & 0.02 & 0.02 & 0.04 & 0.04 \\
\hline
\end{tabular}

Table (3): Effect of dormant pruning treatments on leaf total soluble sugars, starch and total carbohydrates \% of "Anna" apple trees during 2007, 2008 and 2009 seasons.

\begin{tabular}{|c|c|c|c|c|c|c|c|c|c|}
\hline \multirow[t]{2}{*}{ Pruning treatments } & \multicolumn{3}{|c|}{$\begin{array}{c}\text { Total soluble sugars } \\
(\%)\end{array}$} & \multicolumn{3}{|c|}{$\begin{array}{c}\text { Starch } \\
(\%)\end{array}$} & \multicolumn{3}{|c|}{$\begin{array}{c}\text { Total carbohydrates } \\
(\%)\end{array}$} \\
\hline & 2007 & 2008 & 2009 & 2007 & 2008 & 2009 & 2007 & 2008 & 2009 \\
\hline Control & 6.260 & 6.267 & 6.240 & 6.970 & 7.140 & 6.767 & 13.23 & 13.41 & 13.01 \\
\hline Thinning out $20 \%$ & 6.077 & 6.090 & 6.100 & 6.360 & 6.347 & 6.377 & 12.44 & 12.43 & 12.47 \\
\hline Thinning out $40 \%$ & 6.477 & 6.487 & 6.490 & 7.450 & 7.567 & 7.307 & 13.93 & 14.04 & 13.79 \\
\hline Thinning out $60 \%$ & 8.137 & 8.080 & 7.990 & 8.987 & 9.017 & 8.947 & 17.06 & 17.15 & 16.95 \\
\hline LSD at $5 \%$ level & 0.04 & 0.02 & 0.02 & 0.01 & 0.03 & 0.03 & 0.01 & 0.04 & 0.03 \\
\hline
\end{tabular}


Table (4): Effect of dormant pruning treatments on number of flowers/spur and total number of flowers/branch of "Anna" apple trees during 2007, 2008 and 2009 seasons.

\begin{tabular}{|l|c|c|c|c|c|c|}
\hline \multirow{2}{*}{ Pruning treatments } & \multicolumn{3}{|c|}{ Number of flowers/spur } & \multicolumn{3}{c|}{ Total number of flowers/branch } \\
\cline { 2 - 7 } & $\mathbf{2 0 0 7}$ & $\mathbf{2 0 0 8}$ & $\mathbf{2 0 0 9}$ & $\mathbf{2 0 0 7}$ & $\mathbf{2 0 0 8}$ & $\mathbf{2 0 0 9}$ \\
\hline Control & 3.683 & 3.470 & 3.960 & 783.83 & 820.62 & 736.89 \\
\hline Thinning out 20\% & 3.960 & 4.140 & 3.770 & 871.60 & 933.20 & 797.45 \\
\hline Thinning out 40\% & 4.450 & 5.000 & 3.900 & 802.90 & 886.47 & 708.37 \\
\hline Thinning out 60\% & 6.040 & 6.210 & 5.850 & 678.26 & 718.01 & 629.64 \\
\hline LSD at 5\% level & 0.44 & 0.65 & 0.22 & 1.35 & 1.52 & 2.69 \\
\hline
\end{tabular}

Table (5): Effect of dormant pruning treatments on fruit set \% and yield/tree (kg) of "Anna" apple trees during 2007, 2008 and 2009 seasons.

\begin{tabular}{|l|c|c|c|c|c|c|}
\hline \multirow{2}{*}{ Pruning treatments } & \multicolumn{3}{|c|}{ Fruit set( \%) } & \multicolumn{3}{c|}{ Yield/tree (kg) } \\
\cline { 2 - 8 } & $\mathbf{2 0 0 7}$ & $\mathbf{2 0 0 8}$ & $\mathbf{2 0 0 9}$ & $\mathbf{2 0 0 7}$ & $\mathbf{2 0 0 8}$ & $\mathbf{2 0 0 9}$ \\
\hline Control & 23.85 & 24.58 & 23.76 & 22.00 & 23.50 & 20.50 \\
\hline Thinning out 20\% & 24.22 & 25.02 & 24.23 & 25.50 & 33.83 & 24.50 \\
\hline Thinning out 40\% & 25.87 & 26.76 & 26.62 & 24.50 & 28.50 & 23.00 \\
\hline Thinning out 60\% & 25.42 & 26.66 & 26.37 & 19.00 & 20.67 & 17.33 \\
\hline LSD at 5\% level & 0.26 & 0.16 & 0.32 & 0.71 & 1.79 & 0.66 \\
\hline
\end{tabular}

Table (6): Effect of dormant pruning treatments on average yield/tree $(\mathrm{kg})$ and alternate bearing value of "Anna" apple trees during 2007, 2008 and 2009 seasons.

\begin{tabular}{|c|c|c|c|c|}
\hline \multirow[t]{2}{*}{ Pruning treatments } & \multicolumn{2}{|c|}{$\begin{array}{l}\text { Average yield/tree }(\mathrm{kg}) \text { between two } \\
\text { successive seasons }\end{array}$} & \multicolumn{2}{|c|}{ Alternate bearing index } \\
\hline & $2007 \& 2008$ & $2008 \& 2009$ & $2007 \& 2008$ & $2008 \& 2009$ \\
\hline Control & 22.75 & 22.00 & 3.30 & 6.82 \\
\hline Thinning out $20 \%$ & 29.67 & 29.17 & 14.04 & 16.00 \\
\hline Thinning out $40 \%$ & 26.50 & 25.75 & 7.55 & 10.68 \\
\hline Thinning out $60 \%$ & 19.84 & 19.00 & 4.21 & 8.87 \\
\hline LSD at 5\% level & - & - & - & - \\
\hline
\end{tabular}


Table (7): Effect of dormant pruning treatments on fruit weight (g) and firmness Ib/inch ${ }^{2}$ of "Anna" apple trees during 2007,2008 and 2009 seasons.

\begin{tabular}{|l|c|c|c|c|c|c|}
\hline \multirow{2}{*}{ Pruning treatments } & \multicolumn{3}{|c|}{ Fruit weight (g) } & \multicolumn{3}{|c|}{ Fruit Firmness Ib/inch $^{2}$} \\
\cline { 2 - 7 } & $\mathbf{2 0 0 7}$ & $\mathbf{2 0 0 8}$ & $\mathbf{2 0 0 9}$ & $\mathbf{2 0 0 7}$ & $\mathbf{2 0 0 8}$ & 11.54 \\
\hline Control & 97.58 & 102.11 & 100.30 & 11.57 & 11.19 \\
\hline Thinning out 20\% & 102.00 & 109.35 & 105.87 & 11.27 & 11.33 \\
\hline Thinning out 40\% & 103.82 & 114.55 & 109.54 & 11.03 & 10.91 \\
\hline Thinning out 60\% & 108.63 & 116.44 & 112.85 & 11.03 & 10.76 \\
\hline
\end{tabular}

Table (8): Effect of dormant pruning treatments on fruit total soluble solids (TSS) and acidity \% of "Anna" apple trees during 2007,2008 and 2009 seasons.

\begin{tabular}{|c|c|c|c|c|c|c|}
\hline \multirow[t]{2}{*}{ Pruning treatments } & \multicolumn{3}{|c|}{$\operatorname{TSS}(\%)$} & \multicolumn{3}{|c|}{ Total acidity(\%) } \\
\hline & 2007 & 2008 & 2009 & 2007 & 2008 & 2009 \\
\hline Control & 11.03 & 11.09 & 10.95 & 0.597 & 0.590 & 0.597 \\
\hline Thinning out $20 \%$ & 11.76 & 12.02 & 11.45 & 0.530 & 0.530 & 0.530 \\
\hline Thinning out $40 \%$ & 12.21 & 12.52 & 11.88 & 0.510 & 0.490 & 0.507 \\
\hline Thinning out $60 \%$ & 12.50 & 12.70 & 12.29 & 0.490 & 0.460 & 0.470 \\
\hline LSD at $5 \%$ level & 0.02 & 0.03 & 0.02 & 0.02 & 0.04 & 0.03 \\
\hline
\end{tabular}

\begin{tabular}{|c|c|c|c|c|c|c|}
\hline \multirow[t]{2}{*}{ Pruning treatments } & \multicolumn{3}{|c|}{ Total sugar (\%) } & \multicolumn{3}{|c|}{ Starch $(\%)$} \\
\hline & 2007 & 2008 & 2009 & 2007 & 2008 & 2009 \\
\hline Control & 7.920 & 7.967 & 7.850 & 2.597 & 2.537 & 2.627 \\
\hline Thinning out $20 \%$ & 8.330 & 8.430 & 8.190 & 2.567 & 2.517 & 2.587 \\
\hline Thinning out $40 \%$ & 8.517 & 8.607 & 8.380 & 2.507 & 2.467 & 2.517 \\
\hline Thinning out $60 \%$ & 8.657 & 8.767 & 8.490 & 2.423 & 2.407 & 2.410 \\
\hline LSD at $5 \%$ level & 0.010 & 0.020 & 0.020 & 0.050 & 0.090 & 0.005 \\
\hline
\end{tabular}

Table (10): Effect of dormant pruning treatments on red fruit color percentage and peel anthocyanin content $\left(\mu \mathrm{gg.cm}{ }^{2}\right)$ of "Anna" apple trees during 2007,2008 and 2009 seasons.

\begin{tabular}{|c|c|c|c|c|c|c|}
\hline \multirow[t]{2}{*}{ Pruning treatments } & \multicolumn{3}{|c|}{ Red color $(\%)$} & \multicolumn{3}{|c|}{ Peel anthocyanin content $\left(\mu \mathrm{g} . \mathrm{cm}^{2}\right)$} \\
\hline & 2007 & 2008 & 2009 & 2007 & 2008 & 2009 \\
\hline Control & 59.1 & 52.1 & 58.3 & 11.19 & 11.21 & 11.04 \\
\hline Thinning out $20 \%$ & 60.1 & 50.1 & 52.1 & 10.18 & 10.32 & 10.08 \\
\hline Thinning out $40 \%$ & 67.2 & 65.1 & 62.0 & 13.02 & 13.16 & 12.11 \\
\hline Thinning out $60 \%$ & 67.3 & 68.3 & 64.2 & 13.32 & 14.06 & 13.20 \\
\hline LSD at $5 \%$ level & 2.3 & 2.3 & 2.3 & 2.34 & 2.33 & 2.32 \\
\hline
\end{tabular}


and Zayan et al. (2002). They found that dormant pruning treatments increased yield/tree, enhanced revenue/ tree and reduced the yield losses in the bearing apple trees.

Data presented in Table (6) show apple bearing index in "Anna" trees receiving the different pruning treatments . It is evident that all trees receiving pruning treatments were characterized by regular bearing between $(2007$ \& 2008) and (2008 \& 2009) because the alternate index was less than $25 \%$. Similar results were obtained by Stino et al. (1985), Zayan and Morsy (1989) and Kilany and Kilany (1991).

The highest average tree yield in the three seasons was obtained from light dormant pruning (thinning out $20 \%$ of shoots/tree) which gave 29.67 and $29.17 \mathrm{~kg} / \mathrm{tree}$, followed by moderate pruning (thinning out $40 \%$ ) which gave 26.50 and $25.75 \mathrm{~kg} /$ tree. The high tree yield in light dormant pruning treatment may be due to the high total number of flowers/branch.

\subsection{Fruit quality}

Data in Table (7) show that all dormant pruning treatments significantly increased the average fruit weight in comparison with that of the control in the three seasons. Concerning fruit firmness, data clearly showed that in most cases all dormant pruning treatments significantly decreased fruit firmness in comparison with the control in the three seasons.

Such results are in harmony with those obtained by Ferree and Forshey (1988), Fathi and Mokhtar (1998), Zayan et al. (2002) and Gabr et al .2006), who found that dormant pruning increased average fruit weight.

Data of Tables $(8 \& 9)$ reveal that all dormant pruning treatments significantly increased the TSS\% and total sugars\% of apple fruits in comparison with that of the control in the three seasons.

Concerning total acidity $\%$ and total starch\%, data clearly showed that all dormant pruning treatments significantly decreased total acidity\% and total starch\% in comparison with those of the control in the three seasons.

The obtained results are not in agreement with those reported by Ferree and Forshey (1988) who reported that dormant pruning had no effect on soluble solids and total acidity percent of apple fruits, but are in agreement with the findings of Fathi and Mokhtar (1998), Zayan et al. (2002), Gabr and Ibrahim (2005) and Gabr et al. (2006), who showed that dormant pruning treatments increased TSS\% of apple fruits without significant differences when compared with control, except severe pruning (thinning out $60 \%$ of shoots/tree) which significantly increased this value.
Data in Table (10) concerning fruit red color\% and peel content of anthocyanin reveal that treatment of thinning out $60 \%$ of shoots/tree significantly recorded the highest values of both characters compared with the control in the three seasons, followed by treatment of thinning out $40 \%$ of shoots/tree, while thinning out $20 \%$ of shoots/tree treatment had no effect on both parameters. From the aforementioned results one can conclude that dormant pruning treatments affected peel red color\% and content of anthocyanin in proportion to its severity. However, Raese and Williams (1974) reported that low vigor trees developed more colored fruit than high vigor trees. Lakso et al. (1978) found that dormant pruning treatments increased colored fruit percentage. These results could be explained by the findings of Mika (1986) and Proctor and Creasy (1971). Mika (1986) concluded that dormant thinning out treatments facilitate light penetration into the interior part of the tree canopy and increase the rate of photosynthesis, and that this may increase the content of soluble solids in fruits and indirectly improve fruit coloration. Proctor and Creasy (1971) demonstrated that there was minimum light intensity and periodicity requirements for fruit to initiate anthcoyanin pigment synthesis and additionally fruits need a supplementary irradiation period with limited light intensity for induction stage for anthocyanin pigments formation.

Finally, it could be recommended that apple (Anna /Malus) growers should prune their trees by moderate (thinning out $40 \%$ of shoots/tree) to promote flowering and fruit set which in turn increase yield and fruit quality.

\section{REFERENCES}

Abd El-Wahab W.A., Fayed T.A. and Elshenawy I.E. (2002). Effect of some treatments on spur formation on newely introduced Japanese apple cultivars in comparison with Anna apple. Bull. Fac. Agric., Cairo Univ., 53: 639-652.

Association of Official Analytical Chemists A.O.A.C. (1975). Official Methods of Analysis. $12^{\text {th }}$ Ed. Published by A.O.A.C., Washington, D.C., U.S.A.

Babcock, B.A., Lichtenberg E. and Zilberman D. (1992). Impact of damage control and quality of output: estimating pest control effectiveness. Amer. J. Agric. Econ., 74(1):163-172.

Barden J.A. (1974). Net photosynthesis, dark respiration, specific leaf weight, and growth of young apple trees as influnced 
by light regime. J. Amer. Soc. Hort. Sci., 99(6): 547-551.

Barden J.A., DelValle F.B.G. and Myers S.C. (1989). Growth and fruiting of "Delicious" apple trees as affected by severity and season of pruning. J. Amer. Soc. Hort. Sci., 114(2):184-186.

Bertschinger L., Stadler W. and Husistein A. (1997). Control of biennial bearing by pruning? Obust-Und Weinbau., 132(23): 616-617.

Cain J.C. (1973). Foliage canopy development of "McIntosh" apple hedge rows in relation to mechanical pruning the interception of solar radiation and fruiting. J. Amer. Soc. Hort. Sci., 98(4): 357-360.

Dinkova S. (1997). Effect of pruning intensity on the pigment content and leaf size of plum. Rasteniev Dni Nauki., 32(5): 255-256.

Dubois M., Gilles K.A., Eomilton J. K., Robers P. A. and Smith F. (1956). Colorimetric methods for determination of sugar and related substances. Anal. Chem., 28(3): $350-458$.

Ebied M.S. (2005). Comparative Studies on the Effect of Some treatments on Flowering and Fruiting in Different Bearing Sites of Canino Apricot Trees. Ph.D. Thesis, Fac. Agric., Cairo Univ.

Elfving D.C. and Cline R.A. (1990). Growth and productivity of vigorous "Northern Sby" /M.M. 106 apple trees in response to annually applied growth techniques . J. Amer. Soc., Hort. Sci., 115(2): 212-218.

Fathi M.A. and Mokhtar H. (1998). Influence of summer pruning on growth, fruit set and fruit quality of Anna apple trees. Egy. J. of Agri. Res., 76(2): 721-732.

Ferree D.C. and Forshey C.G. (1988). Influence of pruning and urea sprays on growth and fruiting of spur-bound "Delicious" apple trees. J. Amer. Soc. Hort. Sci., 113(5): 699-703.

Forshey C.G. and Marmo C.A. (1985). Pruning and deblossoming effects on shoot growth and leaf of "McIntosh" apple trees. J. Amer. Soc. Hort. Sci., 110(2):128-132.

Freed R.S.P., Eisensmith S.P., Goetez S., Reicosky D., Smail V.W. and P. Wolberg (1989). User's guide to MSTAT-C a software program for the design, management and analysis of agronomic research experiments. Michigan State Univ., U.S.A.

Gabr M.A. and Ibrahim F. A. (2005). Effect of summer pruning, ringing or girdling on growth and yield of trees, quality and storage ability of peach fruits. Avegetative growth, leaf constituents, yield and fruit quality. Proceeding of the $6^{\text {th }}$ Arab. Conf. of Hort. Ismailia, Egypt. 246255.

Gabr M.A., Elbana E.S. and Hussein A.M. (2006). Effect of summer pruning data and severity on vegetative growth, yield and fruit quality of "Canino" apricot trees. Alex. J. Agric. Res., 51(2): 147-156.

Harber R.M., Nyczepir A.P. Yadava U.L. and Sharpe R.R. (1992). Rootstock, pruning and soil fumigation in relation to dormancy and cold hardiness of "Redhaven" peach. Hort. Sci. 27(2):97-100.

Hisa C.L. Luh B.S. and Chichester C.D. (1965): Anthocyanin in freestone peaches. J. food Sci., 30: 5-12

Kilany A.E. and Kilany O. A. (1991): Effect of potassium and boron nutrients on growth, yield and fruit quality of "Anna" apple trees. Bull. Fac. Agric., Cairo Univ. 42(2):415-428.

Kuden A., Son L. and Dennis Jr. F.G. (1997). Effects of different pruning treatments on the yield and quality of apricot. Acta Hort., (441):221-224.

Lakso A.N., Millier W.F., Pellerin R.A. and Carpenter S.G. (1978). Conversion of centeral leader apple trees for improved mechanical harvest. J. Amer. Soc. Hort. Sci., 103(2):284-287.

Lord W.J., Greene D.W. and Damon R.A. Jr. (1979). Flowering of young apple trees following summer pruning. J. Amer. Soc. Hort. Sci., 104(4): 540-544.

Magness J.R. and Taylor G.F. (1925). An improved type of pressure tester for the determination of fruit maturity. U.S. Dept. Agric. 350, 8pp.

Marini R.P. (1985). Vegetative growth, yield and fruit quality of peach as influenced by dormant pruning, summer pruning and summer topping. J. Amer. Soc. Hort. Sci. 110(2): 133-139.

Marini R.P. and Barden J.A. (1987). Summer pruning of apple and peach trees. Hort. Rev., 9:351-375.

Marini R.P. and Sowers D. (1991): Growth, yield and fruit weight of spur-bound Delicious apple tree following spur-pruning and plus $\mathrm{GA}_{4+7}$ application. J. Amer. Soc. Horti. Sci., 116(3): 454-459.

Mika A. (1986). Physiological responses of fruit tree to pruning. Hort. Rev., 8: 337-378.

Nelson N. (1974). A photometric adaptation of the Somogy methods for determination of 
glucose. J. Boil. Chem., 195: 19-23.

Parry M.S. (1981). A comparison of hedgerow and bush tree orchard systems at different within-row spacings with four apple cultivars. J. Hort. Sci., 56(3): 219-235.

Porpiglia P.J. and Barden J.A. (1980). Seasonal trends in net photosynthetic potential, respiration and specific leaf weight of apple leaves as affected by canopy position. J. Amer. Soc. Hort. Sci., 105(6): 920-923.

Proctor J.T.A. and Creasy L.L. (1971). Effects of supplementary light on anthocyanin synthesis in "McIntosh" apples. J.Amer. Soc. Hort. Sci., 96(4): 523-526.

Raese J.T. and Williams M.W. (1974). The relationship between fruit color of "Golden Delicious" apples and nitrogen content and color of leaves. J. Amer. Soc. Hort. Sci., 99(4): 332-334.

Rami M. and Porath D. (1980). Chlorophyll determination in intact tissues using $\mathrm{N}, \mathrm{N}$ dimethyl formamide. Plant Physiol., (65): 478-479.

Rami M. (1982). Formula for determination of chlorophyllous pigments extracted with $\mathrm{N}$, $\mathrm{N}$-dimethyl formamide. Plant Physiol., (69): 1376-1381.
Snedecor G.W. and W.G. Cochran (1972). Statistical Methods $6^{\text {th }}$ Ed. The Iowa State Univ. Press, Ames, Iowa, U.S.A.

Somogy N. (1952). Notes on sugar determination. J. Biol. Chem., 145:19-23.

Stino R.G., Zaki M.M. and Abd El-Aziz A. (1985). Introduction of low chilling apple cultivars in Egypt. Tech. Bulletin 4/1985, Ministry of Agric., A.R.E.

Sus J., Susova V. and Hudsky M. (1997). Effect of pruning on growth of apple trees and on the amount and quality of fruit on slender spindles during the period of full bearing. Vedecke Prace Ovocnarske., 15: 79-88.

Wilcox J.C. (1944). Some factors effecting apple yield in Okanagan valley. Sci. Agric.,(25): 189-213.

Zayan M.A. and Morsy E. (1989). Studies on rest period of "Anna" apple buds under the agroclimatic conditions in northern delta. J. Agric. Res. Tanta. Univ., 15(1): 54-64.

Zayan M.A., Morsy E.; Ayaad H.A. and Gabr M.A. (2002). Influence of pruning treatments on growth, leaf constituents, flowering, yield and fruit quality of "Anna" apple trees. I. Effect of dormant pruning treatments. $2^{\text {nd }}$ Inter. Conf. Horti. Sci., Kafr El-Sheikh, Tanta Univ., Egypt.

$$
\begin{gathered}
\text { النمو والانتاجيه لاشجار تفاح الانا بعد معاملات التقليم الثتوى علاء الدين ثابت ابو العز بساتين الفاكهة ـكلية الزراعه - جامعة سوهاج-مصر }
\end{gathered}
$$

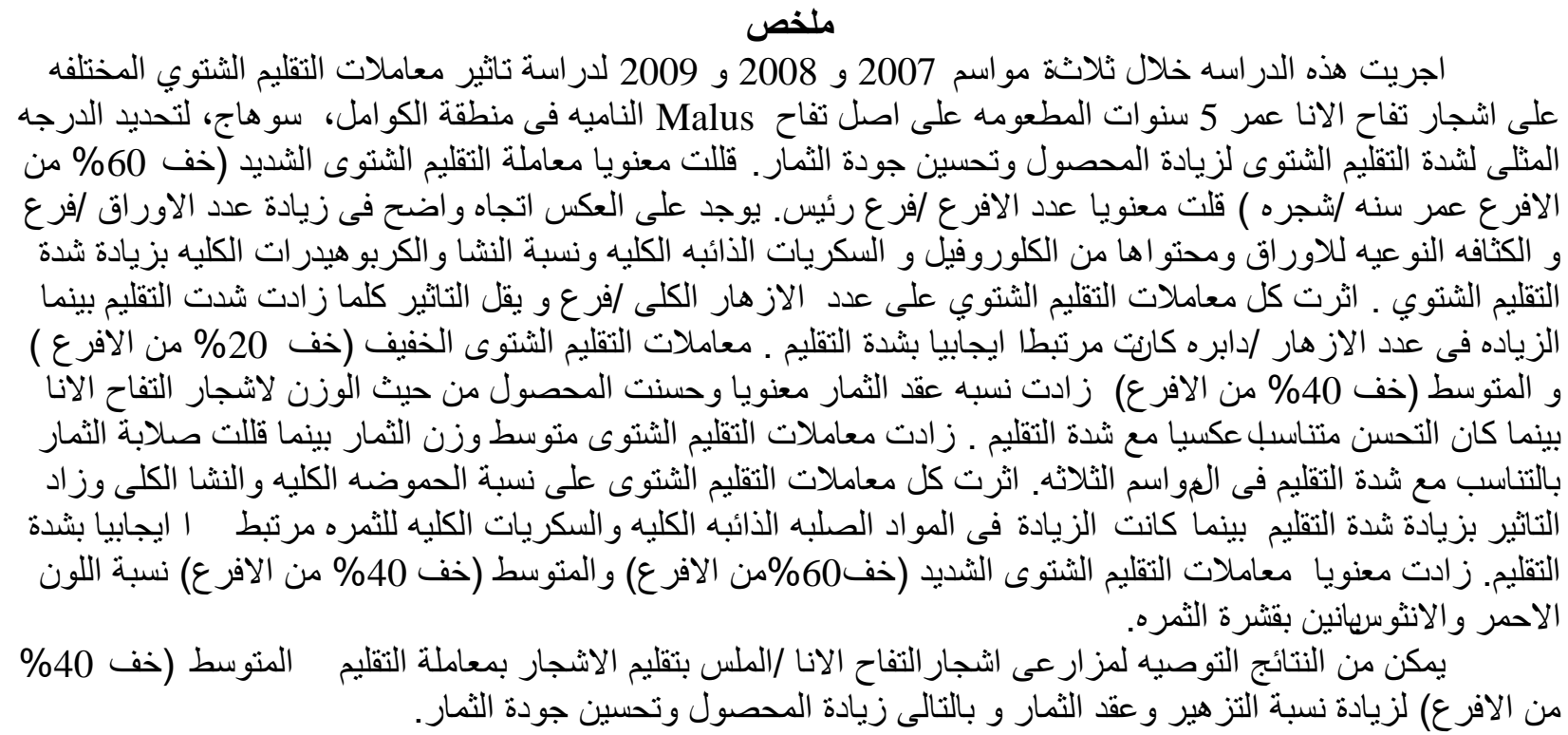

